\title{
PHYSICAL AND PHYSIOLOGICAL CHARACTERISTICS OF POTATO TUBERS RELATED TO STORAGE CONDITIONS
}

\author{
Soliman N. Soliman ${ }^{1}$,Abdel-Wahab S. Kassem ${ }^{1}$ \\ And Azhar El-WershEl-Sayed ${ }^{2}$
}

\begin{abstract}
The aim of this investigation is to study the effect of traditional and cold storage condition on physiological and physical characteristics of Lady Rosetta potato tuber variety, as one of the most important commodity for chips industrials and for exporting, but it is very sensitive for handling and storage. Half ton of fresh tubers of each of two soils cultivar (Sandy and Black soil) were cleaned and the deteriorate tubers were discarded. The tubers were graded into three sizes based on its mass. Potato tubers were cured, then the potatoes of each cultivar were divided into two samples each of $250 \mathrm{~kg}$ for long term storage (200 days) under two different conditions, Nawalla (aerated natural traditional condition), and under cooling condition ( $8 C^{\circ}$ and relative humidity of $85 \%$ ). The results data of fresh and stored potatoes of different storage treatments including physiological and physical characteristics demonstrated graphically and statistical analysis conducted. The physiological measurements are moisture content, sugar content and respiration rate. The physical characteristics measurements are including dimensions, surface area, volume, spherecity, mass, particle and bulk density. Analysis of the results obtained showed that there are linear multiple regression relationships between each of mass loss \%, shrinkage of tuber dimensions \%, shrinkage of volumes \%, particle and bulk density at each of storage condition, storage periods, tubers mass and static load stress for each of sandy and black soil cultivars. Respiration rate ( $\left.\mathrm{mg} \mathrm{CO}_{2} / \mathrm{kg} . \mathrm{h}\right)$ of fresh tubers was directly proportion with tuber specific surface area and inversely proportion with tubers mass for all cultivars. Sugar content (Brix) positively affected by each of type of soil, storage temperature, static load stress, storage time and tuber mass.
\end{abstract}

1- Prof. of Food Engineering, Faculty of Agriculture, Alexandria Univ.

2- Researcher at Agricultural Engineering Research Institute, Agricultural Research Center, Ministry of Agriculture Egypt. 


\section{INTRODUCTION}

otatoes (Solanum tuber osumL.) is consider as one of the most
important vegetables crops in Egypt, which is the second most
important vegetable crop after tomato. The Egyptian production of potatoes increased from 2.3 million tons in 2006 to 4.8 million tons in 2014 for the total area of 1.77 million hectares, according to the NPC, Jul 2016 (National Potato Council, Washington, D.C., USA).

In Egypt, the bulk of potato storage takes place in traditional structures (Nawalla) made of mud bricks. Storage period is normally 5 months take place after curing. However, cold storage facilities are adequate only for a relatively small proportion of the fall/winter seed requirements.

Potatoes used in industries is a very sensitive cultivar for storage conditions and specified by high specific density, high dry matter percent and law sugar content. In order to effectively and efficiently surmount a problem of this magnitude, more basic information concerning the change of physiological and physical behavior of potato tuber under the influence of the applied static load at different storage periods is needed for designing appropriate storage practices.

For "Lady Rosetta" variety, most of the tubers are approximately round. Good storage can merely limit storage losses in good product over relatively long periods of storage. Storage losses are specifies as mass losses and losses in the quality of potatoes. In order to minimize storage losses, the temperature, humidity, light and $\mathrm{CO}_{2}$ content of the air must be within suitable limits; also, it is necessary to use healthy, undamaged and properly cured tubers for storage. In potato these losses are up to $17 \%$ (Eltawil et al., 2006)

Potatoes will remain dormant at $10{ }^{\circ} \mathrm{C}$ for $2-4$ months; since tubers from this temperature are more desirable for both table use and processing than those from $4^{\circ} \mathrm{C}$, late-crop potatoes intended for use within 4 months should be stored at $10^{\circ} \mathrm{C}$ and those for later use at $4^{\circ} \mathrm{C}$. All potatoes should be stored in dark to prevent greening (Eltawil et al., 2006).

Temperature is the most important environmental factor in the post- 
harvest life of fresh vegetables because of its dramatic effect on rates of biological reactions, including respiration. Within the physiological temperature range, the velocity of a biological reaction increases 2 to 3 fold for every $10^{\circ} \mathrm{C}$ rise in temperature according to Van't Hoff s Rule (Kader, 1987; and Bidwell, 1979).

One of the simplest and most effective ways to reduce water loss and decay during post-harvest storage of potatoes is curing after harvest. In root and tuber crops, curing refers to the process of wound healing with the development and suberization of new epidermal tissue called wound periderm.

Dewulf et al. (1999) mentioned that the quality of fruits can be determined by its external and internal characteristics. The most important external characteristics are the size, shape, smell, appearance and product presentation while the most important internal characteristics are the taste and the texture.

The objectives of this work are to study the effects of different storage conditions on the measured quality parameters of potato tubers including each of physiological and physical characteristics for each of fresh and stored potato tubers. These parameters are including respiration rate $(\mathrm{mg}$ $\mathrm{CO}_{2} / \mathrm{kg} . \mathrm{h}$ ), moisture content (wb) \%, sugar content (Brix),tubermass, length, width, thickness, surface area, volume, bulk and particle density and spherecity.

\section{MATERIAL AND METHODS}

Two storage chambers were prepared for conducting storage treatments of potato tubers at Agricultural and Biosystems Engineering Department, Faculty of Agriculture, Alexandria University.

The first type is traditional storage chamber, which was similar to AlNawalla. The Chamber were provided with suction fan of 60 watt on the perforated door and psychrometry.

The second type is refrigeration chamber, which used for each of curing potatoes at $15{ }^{\circ} \mathrm{C}$ and $90 \%$ relative humidity for 15 days and for long storage of potatoes at $8^{\circ} \mathrm{C}$ and $85 \%$ relative humidity. The chambers sanitized before storage. Each chamber was provided with wooden 
shelves with the height of $50 \mathrm{~cm}$ over the ground to support about $500 \mathrm{~kg}$ of potatoes.

Fresh potato variety "Lady Rosetta" which was planted under two different soils sandy soil and black soil, each sample of 500 kilograms were obtained from Daltex company in Kafr El-Zaiat. The selected potato variety specified as a very sensitive cultivar for handling and storage, high density, high dry matter percent and low sugar content.

The fresh potato tubers were manually harvested carefully by hand, cleaned from soiland the tubers which have cuts; skinning, splitting, rot, and greenish were excluded manually, and packaged in pages of 50 kilograms each and transported in the same day by truckto the laboratory.

The fresh potatoes were graded into three different size, small "tubers mass of 70 to $<100 \mathrm{~g}$ ", medium " tubers mass of 100 to $<130 \mathrm{~g}$ " and large " tubers mass of $\geq 130 \mathrm{~g}$ ". The storage were done using three potato size and three levels of static pressure " 0.0, 2.44 and $4.87 \mathrm{kPa}$, which was exerted on the top of the potato cage.

The amount of 36 storage treatments including 6 potato samples which were subjected for 6 storage conditions were done in five replicates. The selected tubers from each size were numbered for preparation and recording the measurements.

The experimental measurements are including tuber mass, dimension (length, width and thickness), volume, bulk and particle density, surface area,respiration rate, moisture content and sugar contents.

Tuber mass was measure using electronic weighing balance with accuracy of 0.01 grams. The tuber dimensions were measure using electronic digital caliper with an accuracy of $0.01 \mathrm{~mm}$.

Tuber volume of potato was measured using displacement technique by alfalfa seeds as described by (Sahin and GulumSumnu, 2006), and the tuber particle density $\left(\rho_{\mathrm{P}}, \mathrm{kg} / \mathrm{mt}^{3}\right)$ was measure based on the measurements of tuber volume, $\left(\mathrm{cm}^{3}\right)$ and tuber mass, (grams).

The bulk density $\left(\rho_{\mathrm{B}}, \mathrm{kg} / \mathrm{mt}^{3}\right)$ of potato tubers was measuredby means of a wooden box with internal dimensions of $30 \times 30 \times 30 \mathrm{~cm}$. The box was 
then, filled with potatoes until the potatoes reached the upper edges of it using a plastic ruler to adjust the flat top surface of the sample. The empty and filled box mass's $\mathrm{M}_{\mathrm{i}}$ and $\mathrm{M}_{\mathrm{f}} \mathrm{in}$ kilograms were determined using people digital balance with an accuracy of $\mp 5$ grams. The bulk density was calculated using the following equation:

$$
\rho_{B}=\frac{\mathbf{M}_{\mathrm{f}}-\mathbf{M}_{\mathrm{i}}}{V_{i}}
$$

The particle and bulk density measuredin five replicate for each treatment.

Surface area of potato tubers were measured according to (Mohsenin, 1986). The tuber was peeled in narrow strips and the sum of the strips areas of tracings of the strips was determined. Specific surface area can be given by the following equation:

$$
S S A=\frac{S A}{M_{o}}
$$

Where: SSA Specific surface area $\left(\mathrm{cm}^{2} / \mathrm{g}\right)$ of individual tuber.

$S A \quad$ Surface areas $\left(\mathrm{cm}^{2}\right)$ of individual potato tubers

$M_{o} \quad$ Fresh mass of individual potato tubers $(\mathrm{g})$.

Tuber spherecitywas calculated according to Mohsenin 1986 using the following equation:

$$
\text { Sphericity }=\frac{\sqrt[3]{L^{*} W^{*} T h}}{d_{C}}
$$

Where: $\boldsymbol{L}, \boldsymbol{W}$ and $\boldsymbol{T h}$ are length width and thickness of potato tubers.

$$
\sqrt[3]{\boldsymbol{L} * \boldsymbol{W} * \boldsymbol{T h}}=\text { geometric mean diameter. }
$$

$\mathrm{d}_{\mathrm{C}}=$ major dimensions.

The moisture content, wet base $\%$ of fresh and stored potato tubers were conducted according to Ghadge et al., 1989.

Total soluble solids (TSS) in the tubers measured by means of the hand held pocket refractometer. Tuber samples taken and manually crushed 
and several drops of the extracted syrup placed on the prism surface to determine the Brix level of the tuber syrup.

The respiration rate test conducted according to the technique described by Singh et al 1969. The respiration rate of potato tubers was determined based on the measurements of carbon dioxide production in milligrams of one-kilogram potato per hours ( $\mathrm{RR}, \mathrm{mg} \mathrm{CO} / \mathrm{kg}$.h)to study the effect of the storage treatments on the shelf life and biological activity of the tuber.

\section{RESULTS AND DISCUSSION}

\subsection{Fresh Condition of Lady Rosetta Potato Tubers:}

\subsubsection{Physical Characteristics}

The fresh potato tubers mass, dimensions (length, width and thickness), volume and particle density were individually measured for a sample of 420 tubers from each tuber size category. Tuber's sphericitywas calculated. Bulk density, moisture content wet base $\%$ and sugar content (Brix) were measured six times for each and for each of sand soil and black soil.

\subsubsection{Tubers mass}

The individual mass of fresh tubers samples was measure. The mass varied through a range of 213.01 and $243.82 \mathrm{~g}$, with a maximum value of 286.83 and317.5 $\mathrm{g}$ anda minimum value of $73.82 \mathrm{~g}$ and $73.68 \mathrm{~g}$ with an average of $120.33 \mathrm{~g}$ and130.978for each of sandy and black soils.

\subsubsection{Tubers dimensions}

The three dimensions of fresh potato tubers Length $(\mathrm{L}, \mathrm{mm})$, Width (W, $\mathrm{mm}$ ) and thickness (Th, $\mathrm{mm}$ ) were measured for each of sandy and black soils cultivar.

The regression analysis between each parameter of physical dimensions and actual initial mass of fresh tubers showed a linear dependence on the initial mass. Therefore, the following linear regression equations were developed in order to correlate the three dimensions of the tubers $(\mathrm{L}, \mathrm{W}$, $\mathrm{Th}, \mathrm{mm}$.) to tubers mass (Mo, g) for each of sandy soils (s) and black soil (b). The statistical regression equations were specified for potato tubers range under study as follow: 
For Sand Soils:

$$
\begin{array}{lll}
\mathrm{L}_{\mathrm{S}}=39.7766+0.1803 \mathrm{M}_{0} \ldots & \mathrm{R}^{2}=0.779, \mathrm{STD}=3.352 \\
\mathrm{~W}_{\mathrm{S}}=42.5029+0.1485 \mathrm{M}_{0} \cdots & \mathrm{R}^{2}=0.829, \mathrm{STD}=2.346 \\
\mathrm{Th}_{\mathrm{S}}=37.2280+0.1163 \mathrm{M}_{0} \cdots & \mathrm{R}^{2}=0.778, \mathrm{STD}=2.164
\end{array}
$$

\section{For Black Soils:}

$$
\begin{array}{lll}
\mathrm{L}_{\mathrm{b}}=40.2880+0.1812 \mathrm{M}_{\mathrm{o}} \ldots & \mathrm{R}^{2}=0.811, \mathrm{STD}=4.084 \\
\mathrm{~W}_{\mathrm{b}}=44.6091+0.1259 \mathrm{M}_{\mathrm{o}} \ldots & \mathrm{R}^{2}=0.829, \mathrm{STD}=2.667 \\
\mathrm{Th}_{\mathrm{b}}=39.2322+0.1028 \mathrm{M}_{\mathrm{o}} \ldots & \mathrm{R}^{2}=0.812, \mathrm{STD}=2.315
\end{array}
$$

The general trend of the measured data showed that the three dimensions of the studied fresh potato tubers directly proportion with fresh mass.

\subsubsection{Tuber volume}

The individual volumes $\left(\mathrm{V}_{\mathrm{o}}, \mathrm{cm}^{3}\right)$ of potato tubers samples were measured. The volumes were varied through a range of 201.522 and230.94 $\mathrm{cm}^{3}$., as maximum as 269.038 and $299.838 \mathrm{~cm}^{3}$ and as minimum as 67.515 and $68.895 \mathrm{~cm}^{3}$ with an average of 115.273 and $125.188 \mathrm{~cm}^{3}$ for each of sandy and black soils.

Linear regression analysis was conducted in order to describe the relationship between volume and mass of tubers and to correlate the tubers volumes $\left(\mathrm{V}_{\text {tuber }}, \mathrm{cu} . \mathrm{cm}\right.$.) to tubers dimensions $(\mathrm{L}, \mathrm{W}, \mathrm{Th}, \mathrm{cm})$ and tubers mass (Mo, g) for each of sandy (s) and black soil (b). The statistical regression equations were as following:

$$
\begin{aligned}
& \mathrm{V}_{\mathrm{s}}=0.9576 \mathrm{Mo} \\
& \mathrm{V}_{\mathrm{s}}=0.5926(\mathrm{~L} * \mathrm{~W} * \mathrm{Th}) \\
& \mathrm{V}_{\mathrm{b}}=0.9555 \mathrm{M}_{\mathrm{o}} \\
& \mathrm{V}_{\mathrm{b}}=0.5879(\mathrm{~L} * \mathrm{~W} * \mathrm{Th})
\end{aligned}
$$$$
\begin{aligned}
& \ldots \ldots . \mathrm{R}^{2}=0.999, \mathrm{STD}=2.186, \\
& \ldots \ldots \mathrm{R}^{2}=0.998, \mathrm{STD}=5.166, \\
& \ldots \ldots . . \mathrm{R}^{2}=0.999, \mathrm{STD}=2.406, \\
& \ldots \ldots . . . \mathrm{R}^{2}=0.996, \mathrm{STD}=7.952,
\end{aligned}
$$$$
\begin{aligned}
& \ldots \ldots . \mathrm{R}^{2}=0.999, \mathrm{STD}=2.186, \\
& \ldots \ldots \mathrm{R}^{2}=0.998, \mathrm{STD}=5.166, \\
& \ldots \ldots . . \mathrm{R}^{2}=0.999, \mathrm{STD}=2.406, \\
& \ldots \ldots . . . \mathrm{R}^{2}=0.996, \mathrm{STD}=7.952,
\end{aligned}
$$$$
\begin{aligned}
& \ldots \ldots . \mathrm{R}^{2}=0.999, \mathrm{STD}=2.186, \\
& \ldots \ldots \mathrm{R}^{2}=0.998, \mathrm{STD}=5.166, \\
& \ldots \ldots . . \mathrm{R}^{2}=0.999, \mathrm{STD}=2.406, \\
& \ldots \ldots . . . \mathrm{R}^{2}=0.996, \mathrm{STD}=7.952,
\end{aligned}
$$

The above equation showed that the tuber volume for the studied fresh potato tubers is directly proportions with the initial tubers mass.

\subsubsection{Particle density}

The particle densities of potatoes weremeasured. The collected data showed randomized relationship between particle density and initial mass 
for each cultivar. For sandy soil cultivar the particle density of Lady Rosetta tubers were changed from 1011.96 up to $1099.3 \mathrm{~kg} / \mathrm{m}^{3}$ with an average of $1044.2 \mathrm{~kg} / \mathrm{m}^{3}$, but for black soil cultivar the particle density of Lady Rosetta tubers were changed from 1013.03 up to $1095.59 \mathrm{~kg} / \mathrm{m}^{3}$ with an average of $1046.486 \mathrm{~kg} / \mathrm{m}^{3}$.

\subsubsection{Bulk density}

The bulk density of potato tubers was determined. The bulk densities of Lady Rosetta tubers for sandy soil were changed from 547 up to 601 $\mathrm{kg} / \mathrm{m}^{3}$ with an average of 584 . For black soil cultivar, the bulk density changed from $555 \mathrm{~kg} / \mathrm{m}^{3}$ up to $607 \mathrm{~kg} / \mathrm{m}^{3}$ with an average of 589 .

The observed data for particle and bulk density of each of sand and black soil cultivars showed that the density of black soil cultivar is slightly larger than that for sandy soil cultivar.

\subsubsection{Tuber Sphericity}

The values of sphericity of Lady Rosetta potato tubers were in the range from 0.7868 to 0.9872 with an average of 0.9153 for sand soil cultivar. While the values of sphericity for black soil cultivars were in the range from 0.7663 to 0.9833 with an average of 0.9086 .

\subsubsection{Tuber surface area}

The surface area $\left(\mathrm{SA}, \mathrm{cm}^{2}\right)$ and specific surface area $\left(\mathrm{SSA}, \mathrm{cm}^{2} / \mathrm{g}\right)$ as a function of initial mass for each soil were determined for 100 fresh potato tubers of each of sand and black soil cultivars. The results show that the tuber surface area was direct proportional with mass and inversely proportion between tuber specific surface area and mass for each of sandy and black soil cultivars. These results agree with Sastry (1985).

The specific surface area (SSA, $\mathrm{cm}^{2} / \mathrm{g}$ ) for fresh potato tubers of sandy soil was changed from 0.6939 to 1.08199 with an average of $0.897 \mathrm{~cm}^{2}$ / g. The specific surface area of black soil tubers were changed from 0.6369 up to $1.09989 \mathrm{~cm}^{2} / \mathrm{g}$ with an average of 0.9042 and with standard error of 0.01328 and standard deviation of 0.11503 .

The surface Area $\left(\mathrm{SA}, \mathrm{cm}^{2}\right)$ for fresh sand soil potato tubers were changed from $73.4889 \mathrm{~cm}^{2}$ up to $162.2886 \mathrm{~cm}^{2}$ with an average 100.8386 . The surface area of black soil potato tubers were changed from 77.723 
$\mathrm{cm}^{2}$ to $184.1186 \mathrm{~cm}^{2}$ with an average of 108.5131 .

Linear regression statistical analysis was conducted to correlate the surface area and specific surface area of tubers to tubers mass (Mo, g) for each of sand soils and black soil. The statistical regression equations were specified for potato tubers range under study as follow:

\section{For Sand Soil}

$\mathrm{SA}_{\mathrm{s}}, \mathrm{cm}^{2}=35.96735+0.56295 \mathrm{M}_{\mathrm{o}} \ldots \mathrm{R}^{2}=0.961, \mathrm{TD}=3.746 \ldots .(14)$

$\mathrm{SSA}_{\mathrm{s}}, \mathrm{cm}^{2} / \mathrm{g}=1.17429-0.00240 \mathrm{M}_{\mathrm{o}} \ldots . \mathrm{R}^{2}=0.802, \mathrm{TD}=0.039 \ldots .(15)$

\section{For Black Soil}

$\mathrm{SA}_{\mathrm{b}}, \mathrm{cm}^{2}=41.93252+0.53075 \mathrm{M}_{\mathrm{o}} \ldots \mathrm{R}^{2}=0.973, \mathrm{STD}=4.172$

$\mathrm{SSA}_{\mathrm{b}}, \mathrm{cm}^{2} / \mathrm{g}=1.18419-0.00223 \mathrm{M}_{\mathrm{o}} \ldots \mathrm{R}^{2}=0.840, \mathrm{STD}=0.046 \ldots$

\subsubsection{Physiological Characteristics}

The physiological characteristics of fresh potato tubers were measured including respiration rate, moisture content wet base $\%$ and sugar content (Brix).

\subsubsection{Respiration rate test}

The respiration rate (RR, $\mathrm{mg} \mathrm{CO} / \mathrm{kg} . \mathrm{h})$ tests of 360 tubers were measured including 60 fresh tubers from each tuber mass group and each soil cultivar. The results showed that the respiration rates for sandy soil fresh potato tubers changed from 2.4964 up to $7.7679 \mathrm{mg} \mathrm{CO} / \mathrm{kg}$.hr with an average 5.631. The respiration rate of black soil tubers were changed from 2.513 up to 11.441 with an average of $7.774 \mathrm{mg} \mathrm{CO}_{2} / \mathrm{kg}$.h .

The results show that the respiration rate directly proportion with tuber specific surface area and inversely proportion with tuber mass for each of sand and black soil cultivars as presented in figure (1). These results agree with Sastry (1985).

Linear regression statistical analysis was conducted to correlate the tubers respiration rate $(\mathrm{RR}, \mathrm{mg} \mathrm{CO} / \mathrm{kg}$.h. $)$ to tubers mass $\left(\mathrm{M}_{\mathrm{o}}, \mathrm{g}\right)$ and to tuber specific surface area (SSA, $\mathrm{cm}^{2} / \mathrm{g}$ ) for each of sand soils and black soil. The statistical regression equations were as follow: 


\section{For Sand Soil}

$$
\begin{aligned}
& \mathrm{RR}_{\mathrm{S}}=10.0539-0.0384 \mathrm{Mo} \ldots . . \mathrm{R}^{2}=0.935, \mathrm{STD}=0.332 \ldots \ldots .(18) \\
& \mathrm{RR}_{\mathrm{S}}=-6.5258+13.5526 \mathrm{SSA} \ldots . \mathrm{R}^{2}=0.842, \mathrm{STD}=0.518 \ldots \ldots(19)
\end{aligned}
$$

\section{For Black Soil}

$$
\begin{aligned}
& R_{\mathrm{b}}=14.3129-0.05273 \mathrm{M}_{\mathrm{o}} \ldots . \mathrm{R}^{2}=0.731, \mathrm{STD}=1.395 \\
& \mathrm{RR}_{\mathrm{b}}=-10.5850+20.3041 \mathrm{SSA} \ldots . . \mathrm{R}^{2}=0.763, \mathrm{STD}=1.311 \ldots . .
\end{aligned}
$$

\subsubsection{Moisture Content and Sugar Content}

The total of 240 tuber samples of fresh potato were prepared for measurements of moisture content and sugar content, the measurements including 120 fresh tubers for each of sand and black soil cultivars. The moisture and sugar contents as a function of initial mass for each cultivar were studied.

The moisture content for fresh sandy soil potato tubers were changed from 71.6681 up to 83.5502 (w.b.\%) with an average 75.583 (w.b. \%). The moisture content of black soil potato tubers were changed from 70 (w.b.\%) to 79.443 with an average of 74.64 (w.b.\%).

The sugar content (Brix) for fresh sand soil potato tubers were changed from 7 (Brix) up 11 (Brix) with an average 8.2 (Brix). The sugar content of black soil potato tubers were changed from 6 (Brix) to 9 (Brix) with an average of 7.7089 (Brix).

\subsection{Storage Treatments:}

\subsubsection{Physical Characteristics:}

Physical characteristics of Lady Rosetta potato tubers during storage periods for the two cultivars, (sand and black soil) under two storage conditions and three levels of static stress were measured each once a month. The measured of air temperature and relative humidity of cooled room and aerated traditional room during storage period which started at first of February are shown in figure (2).

Physical characteristics parameters of storage potato tubers including tuber mass, dimensions (length, width and thickness), volume, bulk and particle density were individually measured for a sample of 420 tubers from each tuber mass group, during the storage period are demonstrated in figures (3 to 10) for all treatments. 
Sand Soil

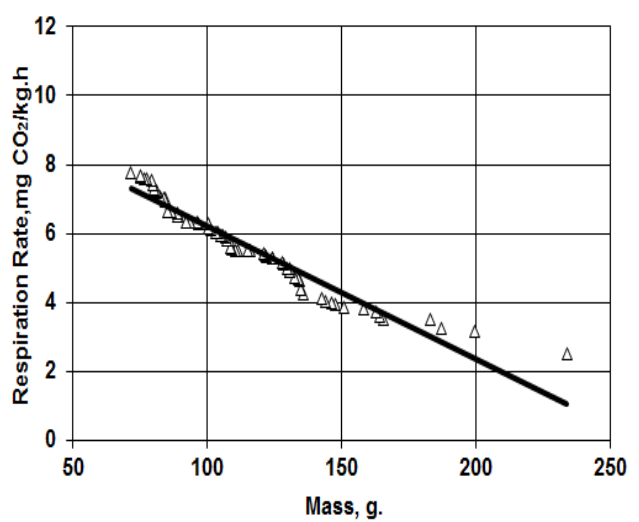

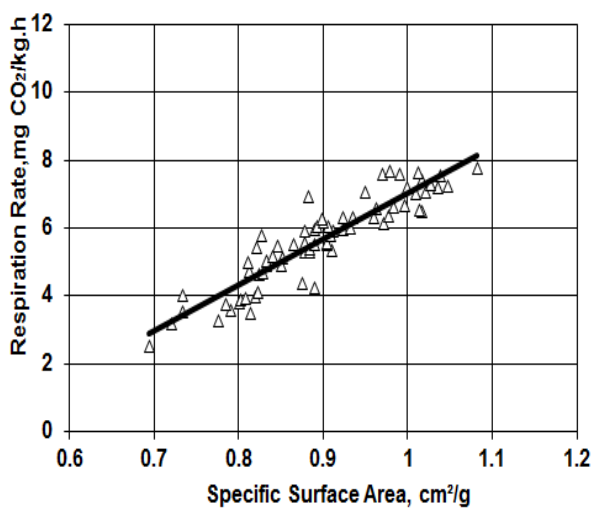

Figure (1): Respiration Rate Directly Proportion with Tuber Specific Surface Area and Inversely proportion with tuber mass.

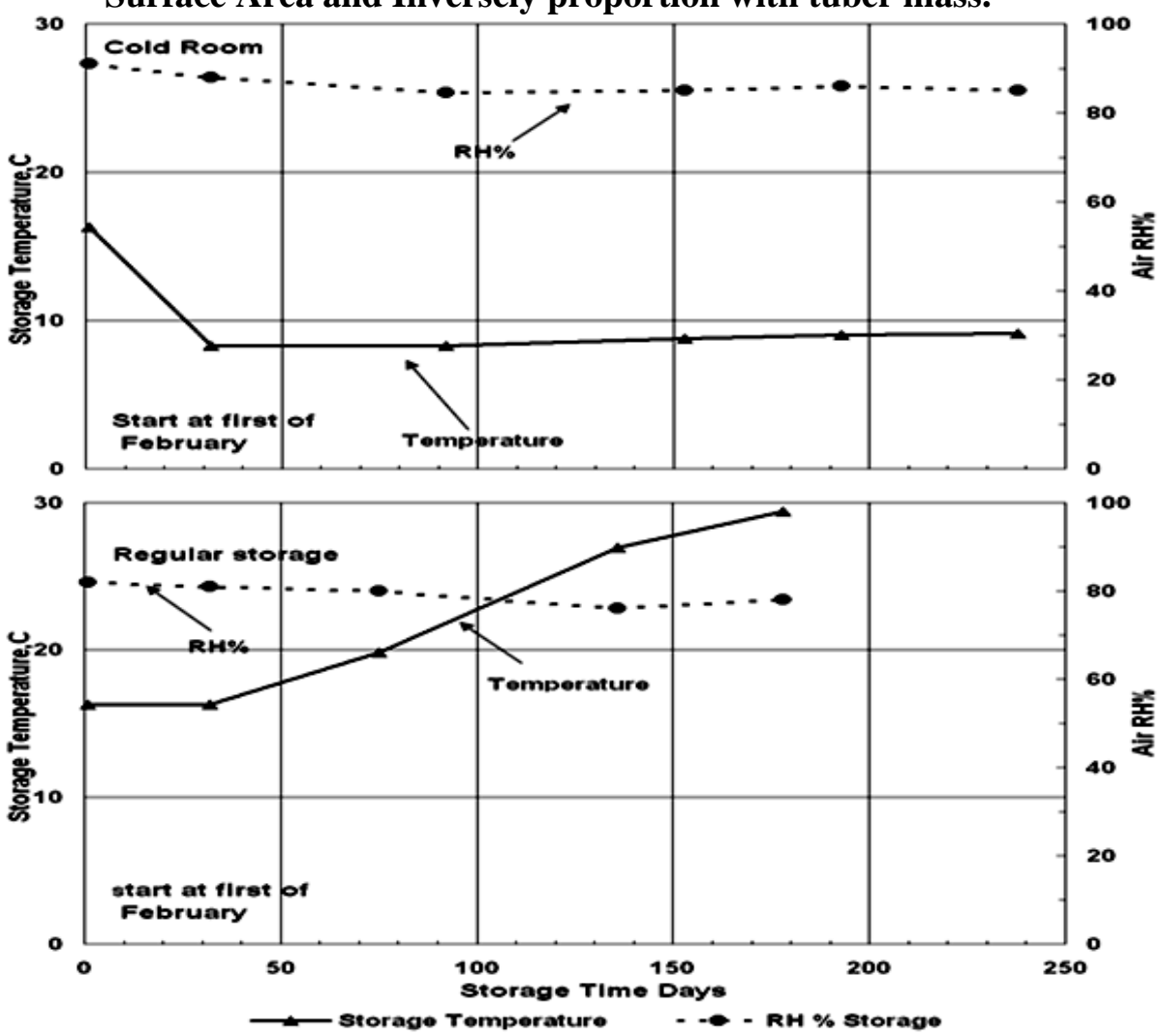

Figure (2): Air Temperature and Relative Humidity during Storage of Potato Tubers under Two Storage Conditions.

\subsubsection{Tubers Mass:}

The individual mass of storage Lady Rosetta variety potato tubers 
samples was measured, and the mass loss $\%$ was calculated within storage time.Figure (3) were demonstrated the relationship of tuber mass loss $\%$ versus tuber mass at different storage time, different static load stress, different storage conditions (cold and traditional storage) and different cultivars (sand and black soil tuber). The graphs show that the initial tuber mass has a very small effect on the mass loss \%, but the storage time has a major effect on mass loss under cooled and traditional storage. The graphs appear that the tuber mass loss \% increases gradually with increasing storage time.

Multiple regression statistical analysis were conducted in order tocorrelate the relationship between tuber mass loss (ML, \%) and each of storage parameters. The storage parameters are including, individual tubers mass (M,gr.), temperature condition $\left(\mathrm{T},{ }^{\circ} \mathrm{C}\right)$ for cold and traditional temperature, storage periods ( $t$, up to 200 day), different static load stress (SL 0.0, 2.44 and $4.87 \mathrm{kPa}$ )and for each of sand and black soil cultivars. The statistical regression analysis clarify that the linear relationship is the best fit equation for describing tuber mass loss and the coefficient of determination is not less than 0.90 for all cases.

The statistical regression equations were as following:

For Sand Soils:

$\mathrm{ML}_{\mathrm{S}}, \%=-11.8179+0.7274 \mathrm{~T}+0.1880 \mathrm{SL}+0.0932 \mathrm{t}+0.0056 \mathrm{M}$,

\section{For Black Soils:}

$$
\ldots \ldots . \mathrm{R}^{2}=0.859, \mathrm{STD}=3.611
$$

$\mathrm{ML}_{\mathrm{b}}, \%=-11.9135+0.5843 \mathrm{~T}+0.1286 \mathrm{SL}+0.0842 \mathrm{t}+0.0260 \mathrm{M}$, $\mathrm{R}^{2}=0.825, \mathrm{STD}=3.664 \ldots$

\subsubsection{Tubers dimensions}

The three dimensions of storage Lady Rosetta variety potato tubers samples Length (L, mm), Width (W, mm) and thickness (Th, mm) were measured and the change of dimension $\%$ were calculated at different times for all conditions.

Figure (4) demonstrated the relationship of tuber change in length $\Delta \mathrm{L} \%$ (as ample) versus storage parameters (SP) which include storage time, different static load stress, different cultivars (sand and black soil tuber) and at different storage conditions (cold and traditional storage). 


\section{Sand Soil}

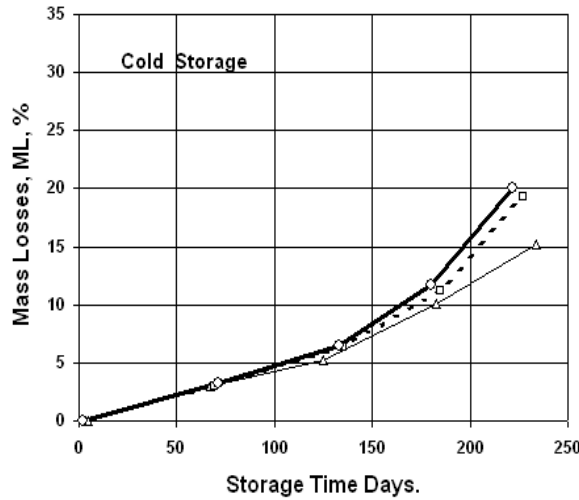

$\longrightarrow$ At $0.0 \mathrm{KPa}-$ - - - At $2.44 \mathrm{KPa} \longrightarrow$ At $4.87 \mathrm{KPa}$

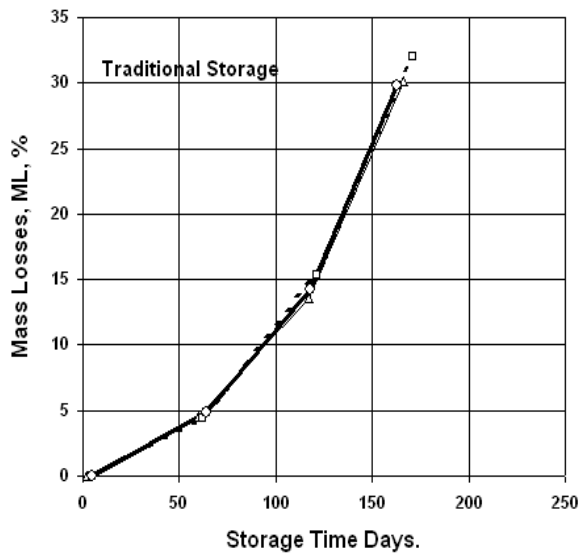

$\longleftarrow$ At $0.0 \mathrm{KPa}--\square-$ At $2.44 \mathrm{KPa} \longrightarrow$ At $4.87 \mathrm{KPa}$

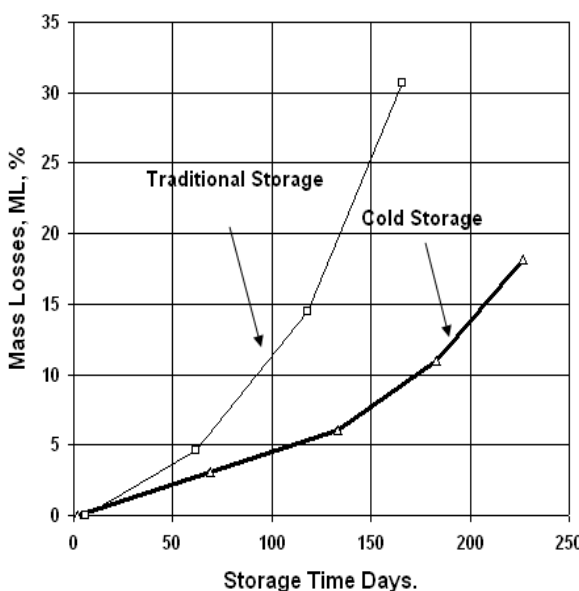

$\longrightarrow$ At Cold Storage $\rightarrow-$ At Traditional Storage
Black Soil
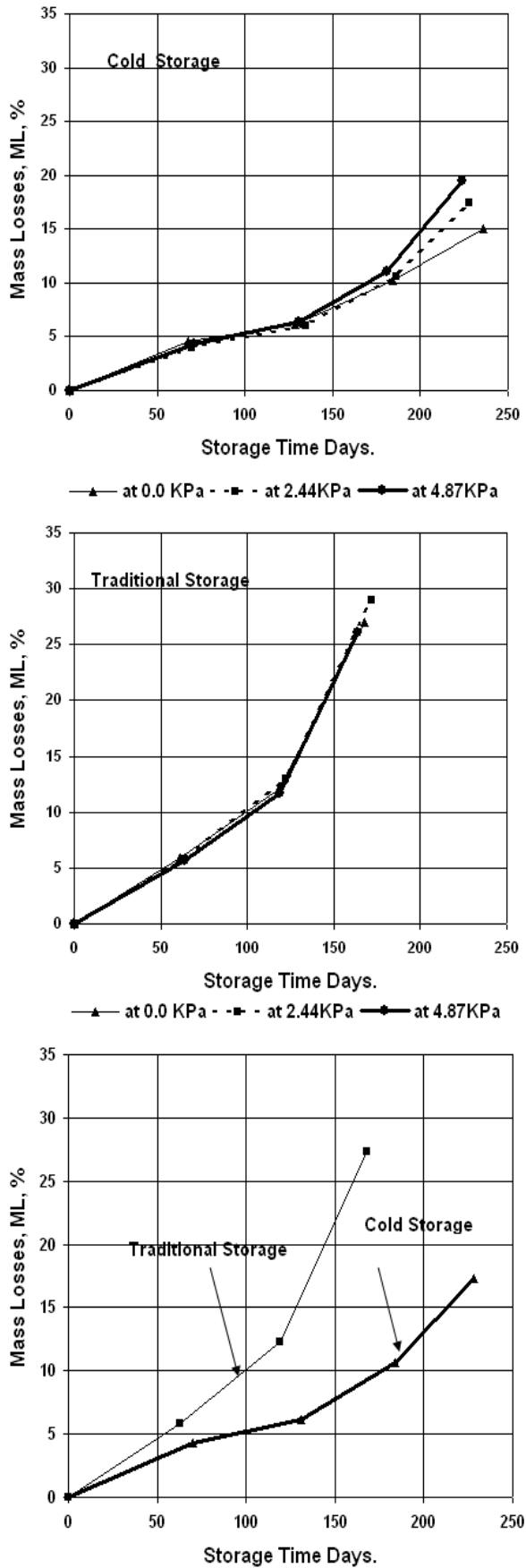

- at Cold Storage $\rightarrow-$ at Traditional Storage

Figure (3): Effect of Storage Time on Mass Losses of Sand and Black Soils Tubers on Two Storage Conditions at Different Static Stress. 
Sand Soil

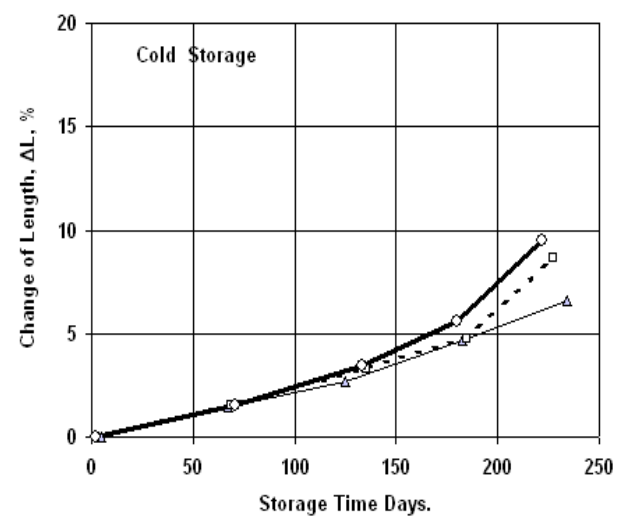

$\longrightarrow$ At $0.0 \mathrm{KPa}--\mathrm{a}-$ At $2.44 \mathrm{KPa}=$ At $4.87 \mathrm{KPa}$

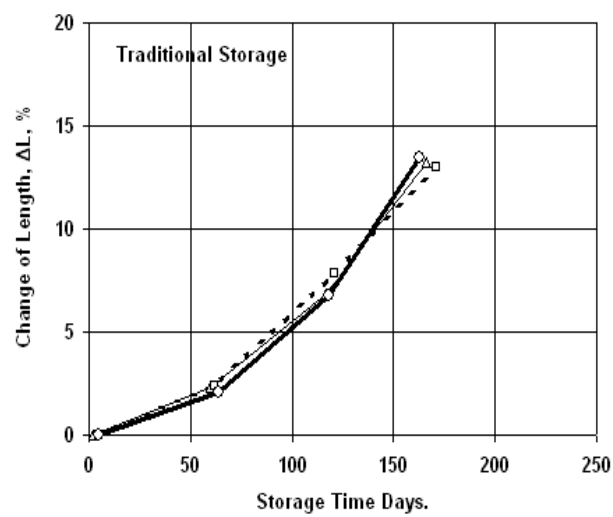

$\longrightarrow$ At $0.0 \mathrm{KPa}--\mathrm{a}-$ At $2.44 \mathrm{KPa} \longrightarrow$ At $4.87 \mathrm{KPa}$

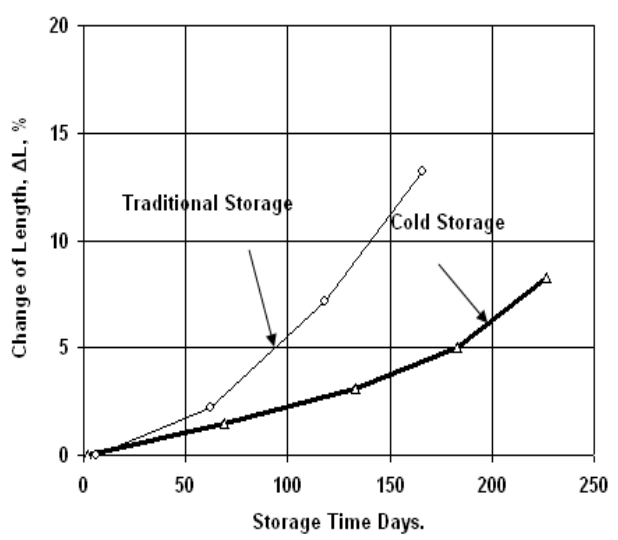

$\longrightarrow$ At Cold Storage $\sim$ At Traditional Storage
Black Soil

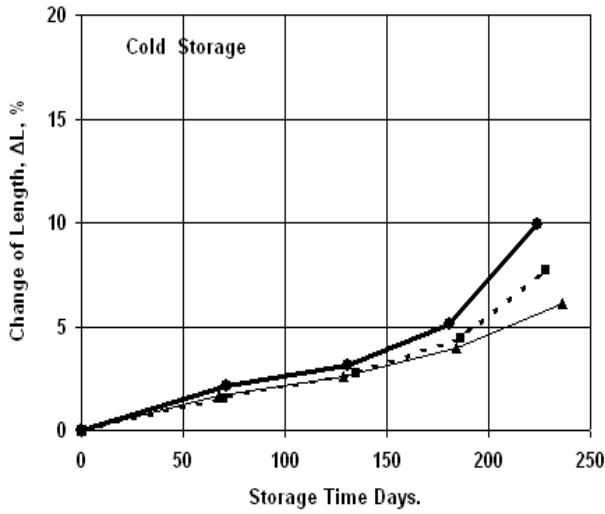

$\longrightarrow$ at $0.0 \mathrm{KPa}--\mathrm{F}-$ at $2.44 \mathrm{KPa} \longrightarrow$ at $4.87 \mathrm{KPa}$

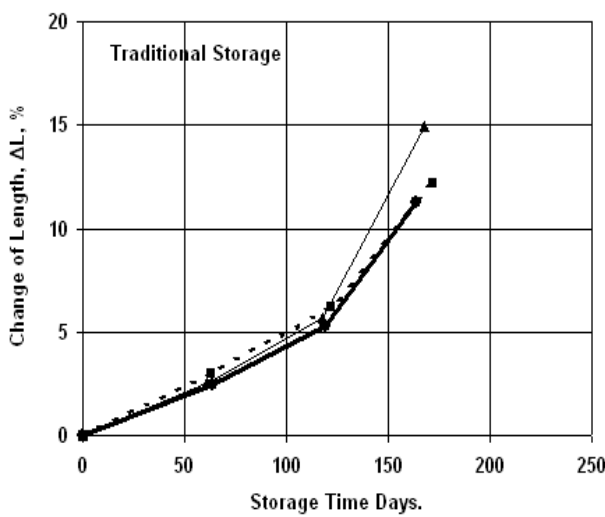

$\longrightarrow$ at $0.0 \mathrm{KPa}-- \pm-$ at $2.44 \mathrm{KPa} \longrightarrow$ at $4.87 \mathrm{KPa}$

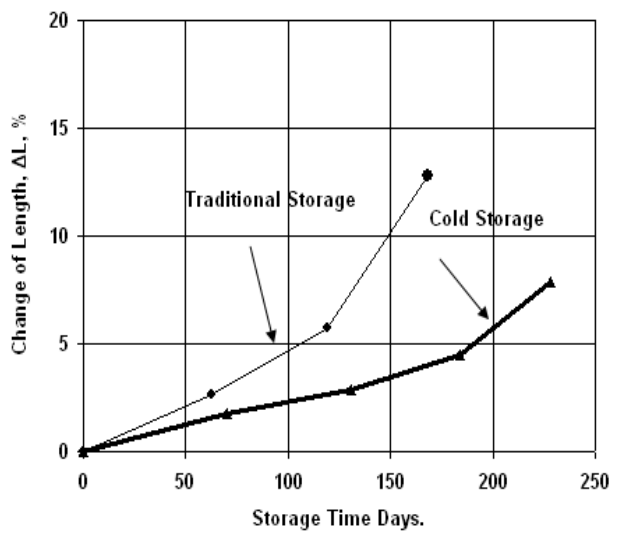

$\longrightarrow$ at Cold Storage $\rightarrow$ at Traditional Storage

Figure (4): Effect of Storage Time on Length of Sand and Black Soil Potato Tubers on Two Storage Conditions at Different Static Stress. 
The graphs appear that the tuber change of dimensions \% increases gradually with increasing storage time. The general trend of the measured data showed that the change of three dimensions $\%$ of the studied storage potato tubers directly proportion with storage time.

Linear multiple regression statistical analysis was conducted to clarify the relationship between change of tuber dimensions \% during storage and each of storage parameters. The statistical regression equations were shown as follow:

\section{For Sand Soils:}

$$
\begin{array}{r}
\Delta \mathrm{L}_{\mathrm{S}}, \%=-5.1604+0.3904 \mathrm{~T}+0.0825 \mathrm{SL}+0.0487 \mathrm{t}-0.0033 \mathrm{M} \\
\ldots . \mathrm{R}^{2}=0.794, \quad \mathrm{STD}=1.945 \ldots \\
\Delta \mathrm{W}_{\mathrm{S}}, \%=-6.8567+0.4613 \mathrm{~T}+0.1301 \mathrm{SL}+0.0601 \mathrm{t}+0.0005 \mathrm{M} \\
\ldots . \mathrm{R}^{2}=0.809, \quad \mathrm{STD}=2.277 \ldots \\
\begin{array}{r}
\Delta \mathrm{Th}_{\mathrm{S}}, \%=-8.0988+0.5642 \mathrm{~T}+0.0906 \mathrm{SL}+0.0716 \mathrm{t}-0.0012 \mathrm{M} \\
\ldots \mathrm{R}^{2}=0.772, \quad \mathrm{STD}=3.048 \ldots
\end{array}
\end{array}
$$

\section{For Black Soils:}

$$
\begin{array}{r}
\Delta \mathrm{L}_{\mathrm{b}}, \%=-4.2174+0.3416 \mathrm{~T}+0.0489 \mathrm{SL}+0.0436 \mathrm{t}-0.0035 \mathrm{M} \\
\ldots . \mathrm{R}^{2}=0.739, \quad \mathrm{STD}=2.093 \ldots(27) \\
\Delta \mathrm{W}_{\mathrm{b}}, \%=-5.3797+0.4014 \mathrm{~T}+0.0282 \mathrm{SL}+0.0513 \mathrm{t}-0.00126 \mathrm{M} \\
\ldots . \mathrm{R}^{2}=0.742, \quad \mathrm{STD}=2.428 \ldots(28) \\
\Delta \mathrm{Th}_{\mathrm{b}}, \%=-6.6039+0.5168 \mathrm{~T}+0.0053 \mathrm{SL}+0.0618 \mathrm{t}-0.0038 \mathrm{M} \\
\ldots . \mathrm{R}^{2}=0.697, \quad \mathrm{STD}=3.294 \ldots(29)
\end{array}
$$

\subsubsection{Tuber volume:}

The change of volumes $(\Delta \mathrm{V}, \%)$ of investigated potato tubers for each soil were investigated versus storage parameters (SP) and demonstrated in figures (5).The general trend of the measured data showed that the shrinkage of Volume, $\Delta \mathrm{V}, \%$ of the studied storage potato tubers directly proportion with storage time.

Linear multiple regression statistical analysis was conducted to clarify the relationship between tuber shrinkage of volume, $\Delta \mathrm{V}, \%$ during storage and storage parameters. The statistical regression equations were shown as follow:

\section{For Sand Soils:}

$$
\begin{array}{r}
\Delta \mathrm{V}_{\mathrm{S}}, \%=-14.3199+0.9579 \mathrm{~T}-0.0895 \mathrm{SL}+0.1282 \mathrm{t}-0.0080 \mathrm{M} \\
\ldots \quad \mathrm{R}^{2}=0.8080, \mathrm{STD}=4.8832 \ldots \ldots
\end{array}
$$




\section{For Black Soils}

$$
\begin{array}{r}
\Delta \mathrm{V}_{\mathrm{b}}, \%=-10.9624+0.7336 * \mathrm{~T}+0.1066 \mathrm{SL}+0.1202 \mathrm{t}+0.0039 \mathrm{M} \\
\ldots \mathrm{R}^{2}=0.8375, \mathrm{STD}=4.1614 \ldots \ldots .(31)
\end{array}
$$

\subsubsection{Particle density}

The particle densities $\left(\boldsymbol{\rho}_{\mathbf{p}}, \mathbf{k g} / \mathbf{m}^{3}\right)$ of storage potato tubers with storage time demonstrated in figure (6).The general trend of the calculated data showed that the particle density of potato tubers of the studied storage potato tubers directly proportion with storage time.

Linear multiple regression statistical analysis conducted to clarify relationship between particle density $\left(\rho_{\mathrm{p}}, \mathbf{k g} / \mathbf{m}^{3}\right)$ of potato tubers during storage and storage parameters. The statistical regression equations were as follow:

\section{For Sand Soils:}

$$
\begin{array}{r}
\boldsymbol{\rho}_{\mathrm{ps}}, \mathrm{Kg} / \mathrm{m}^{3}=997.383+3.4836 \mathrm{~T}-2.3675 \mathrm{SL}+0.5520 \mathrm{t}-0.0981 \mathrm{M} \\
\ldots \ldots \mathrm{R}^{2}=0.782, \mathrm{STD}=22.860 \ldots
\end{array}
$$

\section{For Black Soils}

$$
\begin{array}{r}
\boldsymbol{\rho}_{\mathrm{pb}}, \mathrm{Kg} / \mathrm{m}^{3}=1025.262+0.8248 \mathrm{~T}+0.7915 \mathrm{SL}+0.5379 \mathrm{t}-0.0969 \mathrm{M} \\
\ldots \ldots \mathrm{R}^{2}=0.892, \mathrm{STD}=15.079 \ldots
\end{array}
$$

\subsubsection{Bulk density}

The bulk densities $\left(\boldsymbol{\rho}_{\boldsymbol{B}}, \mathbf{k g} / \mathbf{m}^{3}\right)$ of potato tubers under investigation were determined for all treatments and the observed data for bulk density of each of sand and black soil cultivars showed that the density of black soil cultivar is slightly larger than that for sand soil cultivar as shown in figure (7).

Linear multiple regression statistical analysis was conducted to clarify the relationship between tuber bulk density $\boldsymbol{\rho}_{B}, \mathrm{~kg} / \mathrm{m} 3$ of potato tuber during storage and each of storage condition (cold and traditional temperature)storage periods (20,60, 120, and 200 day) and as a function of soil type ( ST,1 for sandy and 2 for black soil). For all data the statistical regression equations were as follow:

$\boldsymbol{\rho}_{B}, \mathrm{Kg} / \mathrm{m}^{3}=565.3845+5.5416 \mathrm{ST}+0.3164 \mathrm{~T}+0.1767 \mathrm{t}$

\subsubsection{Physiological Characteristics:}

$$
\ldots . . \mathrm{R}^{2}=0.942, \mathrm{STE}=3.532 \ldots
$$

The physiological characteristics tests of Lady Rosetta storage potato tubers were investigated include respiration rate test and each of moisture content wet bases (\%) and sugar content (Brix) as a destructive test which were measured using five tubers from each treatment each about one month. 
Sand Soil
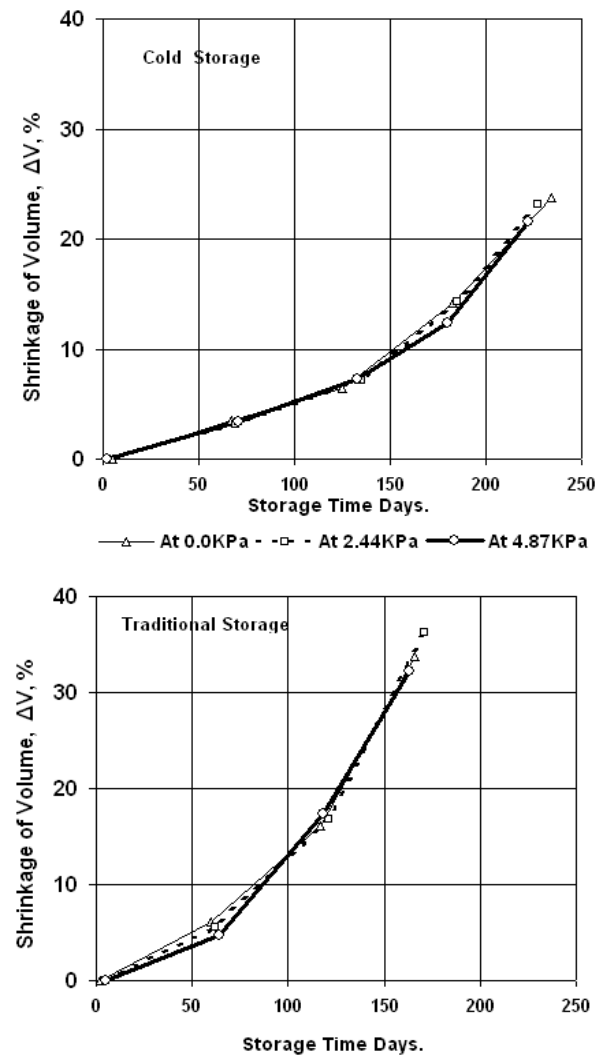

$\longrightarrow$ At $0.0 \mathrm{KPa}-$ - - - At $2.44 \mathrm{KPa} \longrightarrow$ At $4.87 \mathrm{KPa}$

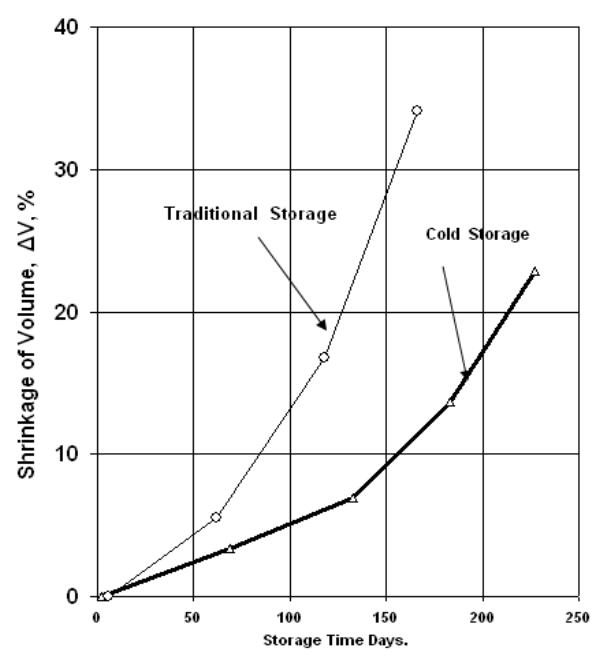

$\longrightarrow$ At Cold Storage $-\infty$ At Traditional Storage
Black Soil
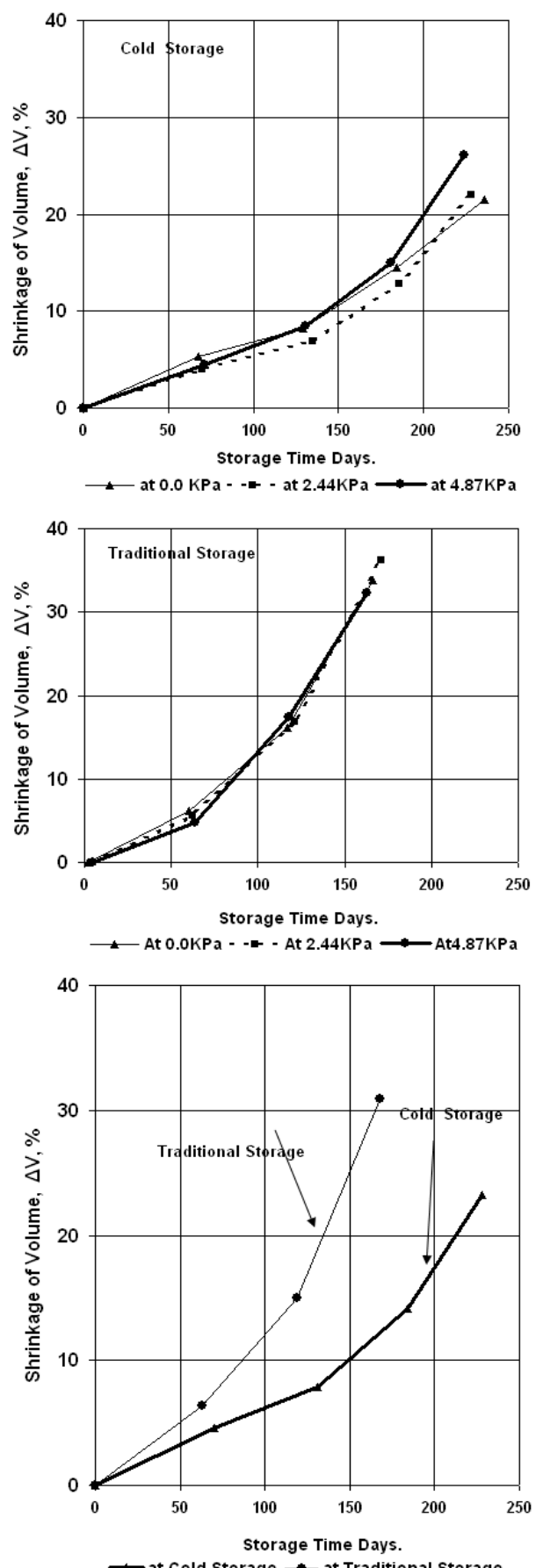

Figure (5): Effect of Storage Time on Volume Shrinkage of Potato Tubers under Two Storage Conditions at Different Static Stress. 


\section{Sand Soil}

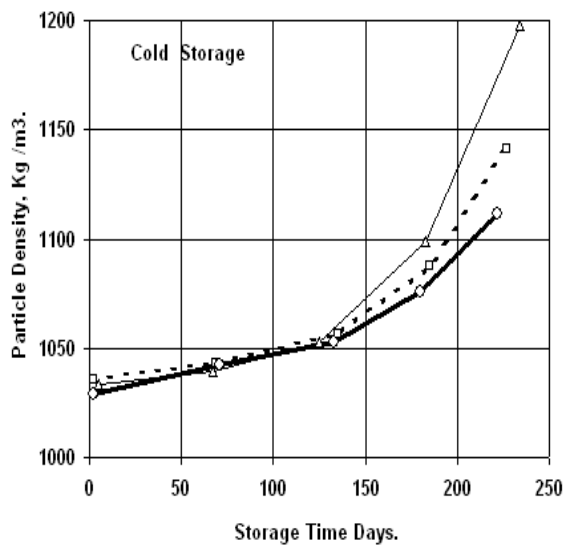

$\longrightarrow$ At $0.0 \mathrm{KPa}-\cdot-$ - At $2.44 \mathrm{KPa} \longrightarrow$ At $4.87 \mathrm{KPa}$

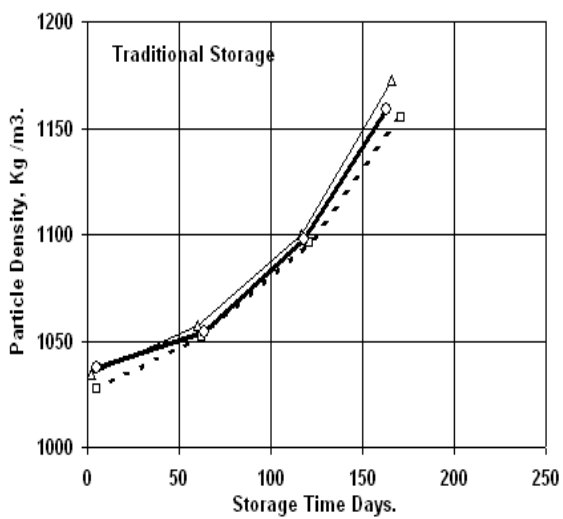

$\longrightarrow$ At $0.0 \mathrm{KPa}-\cdot \mathrm{-}-$ At $2.44 \mathrm{KPa} \longrightarrow$ At $4.87 \mathrm{KPa}$

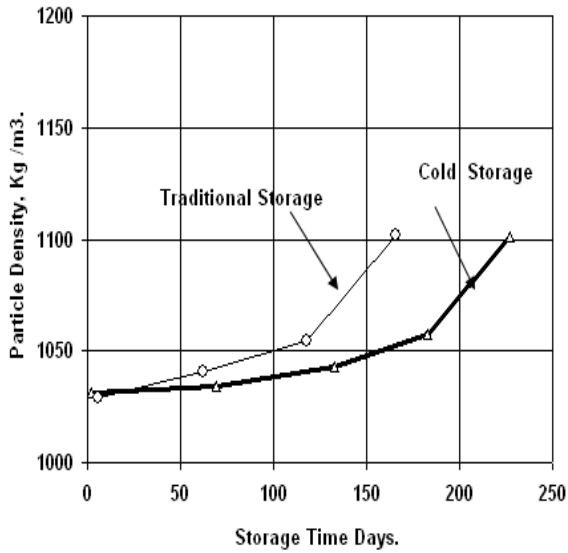

$\longrightarrow$ At Cold Storage $-\infty$ At Traditional Storage

\section{Black Soil}

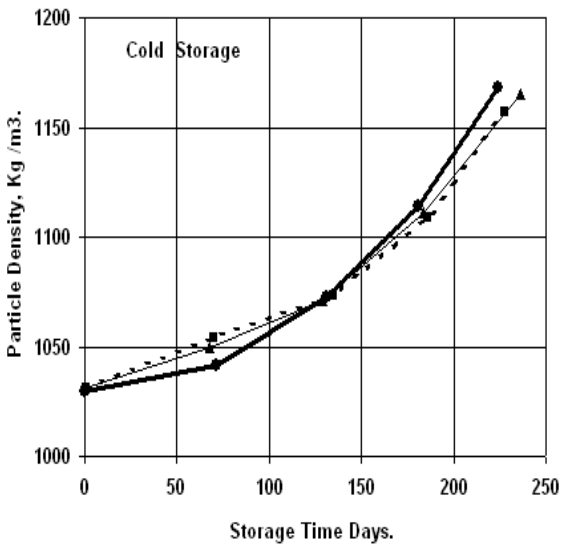

$\longrightarrow$ at $0.0 \mathrm{KPa}-\cdots \cdot$ at $2.44 \mathrm{KPa} \longrightarrow$ at $4.87 \mathrm{KPa}$

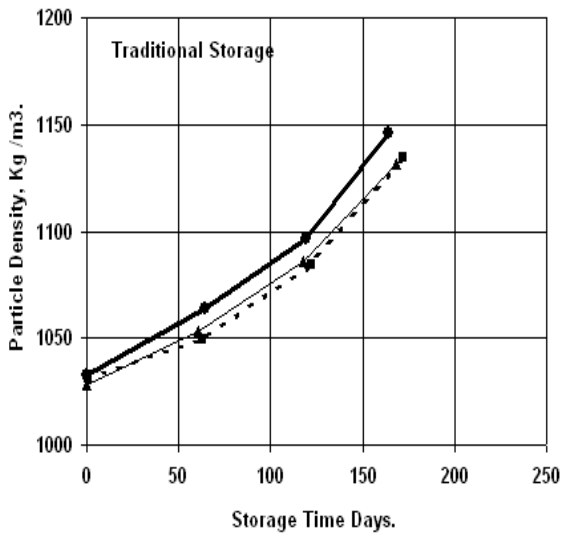

$\longrightarrow$ at $0.0 \mathrm{KPa}--\mathrm{E}-$ at $2.44 \mathrm{KPa} \longrightarrow$ at $4.87 \mathrm{KPa}$

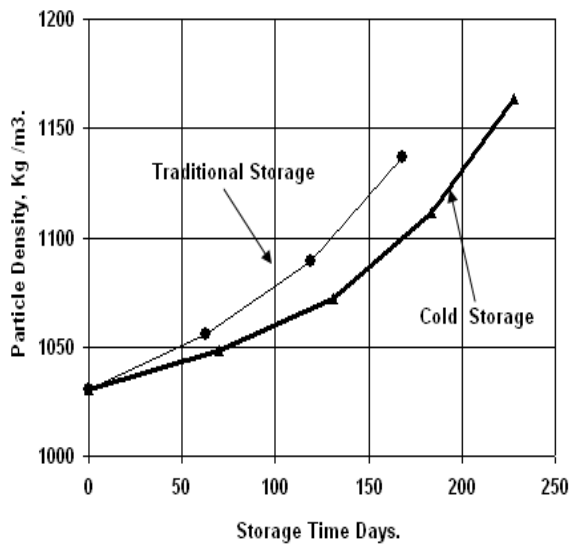

-at Cold Storage $\rightarrow$ - at Traditional Storage

Figure (6): Effect of Storage Time on Particle Density of Potato Tubers at Two Storage Conditions and at Different Static Stress. 
Cold Sorage

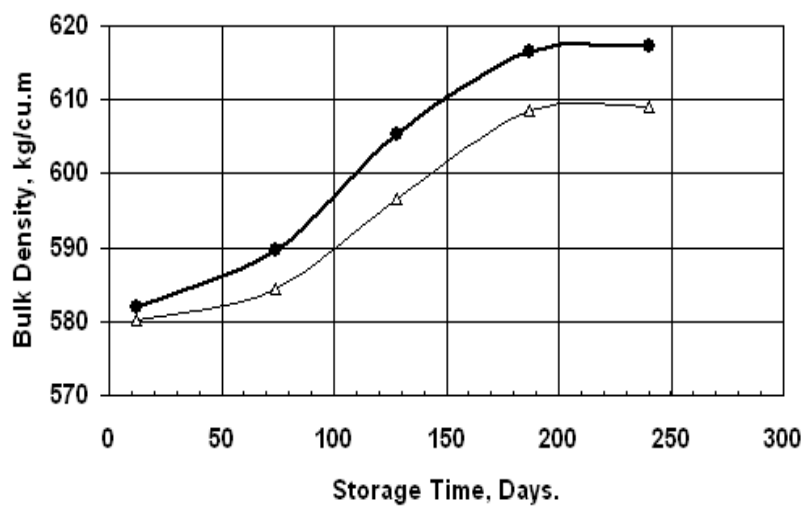

Traditional Storage

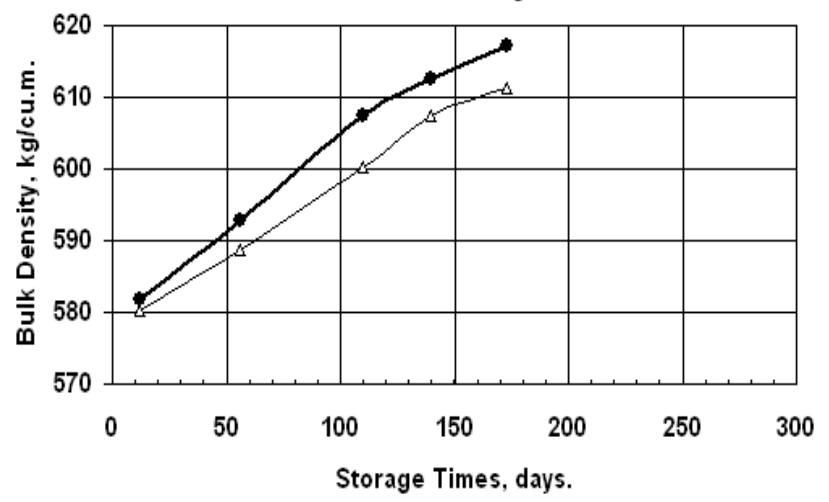

Figure (7): Effect of Storage Time on Bulk Density of Potato Tubers Under Two Storage Conditions Cold and Traditional.

\subsubsection{Respiration rate test:}

The individual respiration rate test of 360 tubers were measured including two cultivars (Sand and black soil), two storage condition (cold and traditional), three mass groups, three static load and ten replicates from each treatment. The respiration tests were measured at each month during the storage period.

Figure (8) represent the respiration rate (RR, $\mathrm{mg} \mathrm{CO} / \mathrm{kg} . \mathrm{h}$ ) of storage potato tubers versus storage parameters (SP). The results of traditional storage show that respiration rate decrease with time up to increasing storage about 75 day and then the rate respiration increasing gradually with increasing storage time for each of sand and black soil.

While at cold storage, the respiration rate decreasing up to 96 days and then the respiration rate almost stays constant during the storage time for 
black soil, but the respiration rate of sand soil cultivar at cold storage increasing slowly with increasing storage time.

Non-linear multiple regression statistical analysis was conducted in order to clarify the relationship between respiration rate (RR, $\left.\mathrm{mg} \mathrm{CO}_{2} / \mathrm{kg} . \mathrm{h}\right)$ of potato tubers during storage and storage parameters. For all data the statistical regression equations were as follow:

\section{For Sand Soils:}

Ln RRs $=0.1032 \mathrm{~T}-0.0079 \mathrm{SL}+0.0088 \mathrm{t}-0.0018838 \mathrm{M}$

\section{For Black Soils:}

$$
\ldots \mathrm{R} 2=0.965, \mathrm{STD}=0.4395 \ldots(35)
$$

$\mathrm{Ln} \mathrm{RRb}=0.1214 \mathrm{~T}-0.0105 \mathrm{SL}+0.0046 \mathrm{t}-0.00095 \mathrm{M}$

\subsubsection{Moisture Content and Sugar Content}

$$
\ldots \mathrm{R} 2=0.903, \mathrm{STD}=0.6579 \ldots(36)
$$

The total of 288 tubers samples of storage potato were prepared for measurements of moisture content and sugar content. The measured samples were including, two cultivars (sand and black soil), two-storage condition (cold and traditional), three mass groups; three load stress and eight replicates from each treatment. Figures (9) represent moisture content (M.C.wb) of storage potato tubers as a function of storage time for each of sand and black soil cultivars.

The results of individual moisture content tests show that moisture content increase with increasing storage time up to about 90 day and then decreasing gradually with increasing storage time at cold storage for each of sand and black soil. While at traditional storage the values of moisture content decreasing gradually during the storage time for each of sand and black soil.

Non-linear multiple regression statistical analysis was conducted to clarify the relationship between moisture content (M.C.wb, \%) and storage parameters. The statistical regression equations are shown as follow:

\section{For Sand Soil Cultivars:}

$\operatorname{Ln}($ M.C.w.b.\%) $=0.0175 \mathrm{~T}+0.0075 \mathrm{SL}+0.0044 \mathrm{t}+0.0317 \mathrm{M}$

$$
\ldots \mathrm{R}^{2}=0.997, \mathrm{STD}=0.239
$$

\section{For Black Soil Cultivars:}

$$
\begin{array}{r}
\text { Ln (M.C.w.b.\%) }=0.0155 \mathrm{~T}-0.0019 \mathrm{SL}+0.0048 \mathrm{t}+0.0316 \mathrm{M} \\
\ldots \mathrm{R}^{2}=0.997, \mathrm{STD}=0.235 \ldots
\end{array}
$$


Sand Soil

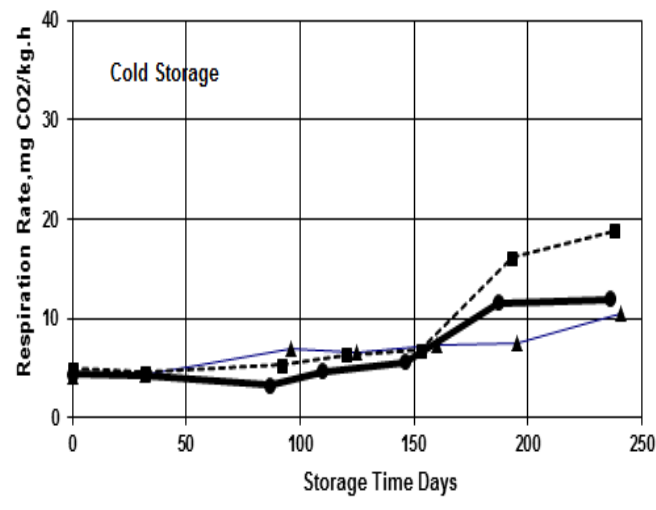

$\rightarrow$ at $0.0 \mathrm{Kpa}--\cdots$ at $2.44 \mathrm{Kpa} \longrightarrow$ at $4.87 \mathrm{Kpa}$

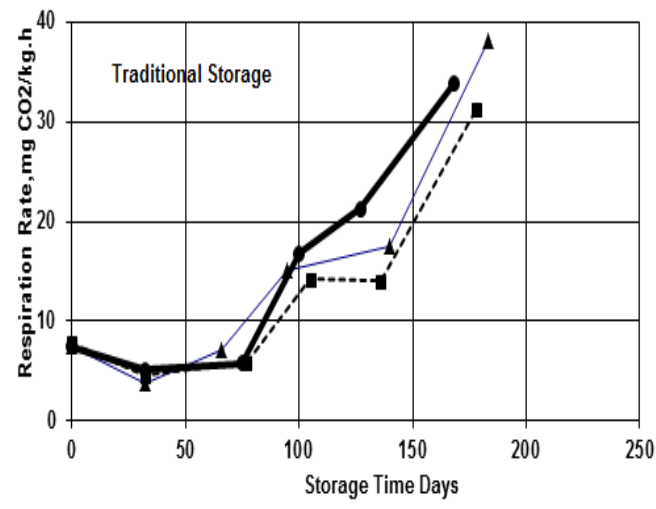

$\rightarrow$ at $0.0 \mathrm{Kpa}--\rightarrow-$ at $2.44 \mathrm{Kpa} \sim$ at $4.87 \mathrm{Kpa}$

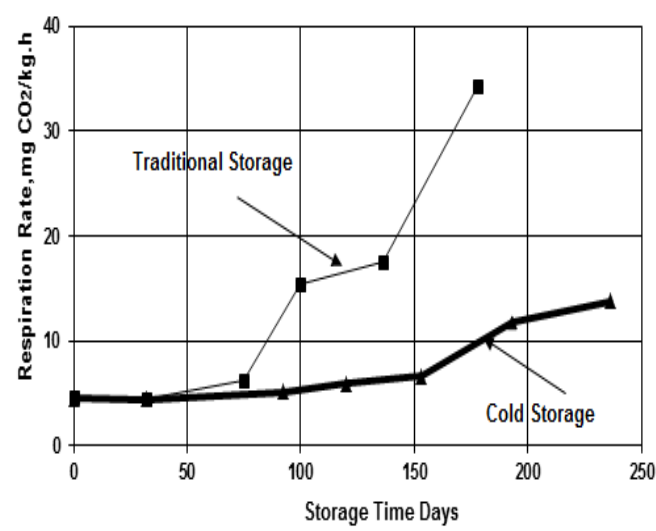

At Cold Storage
Black Soil

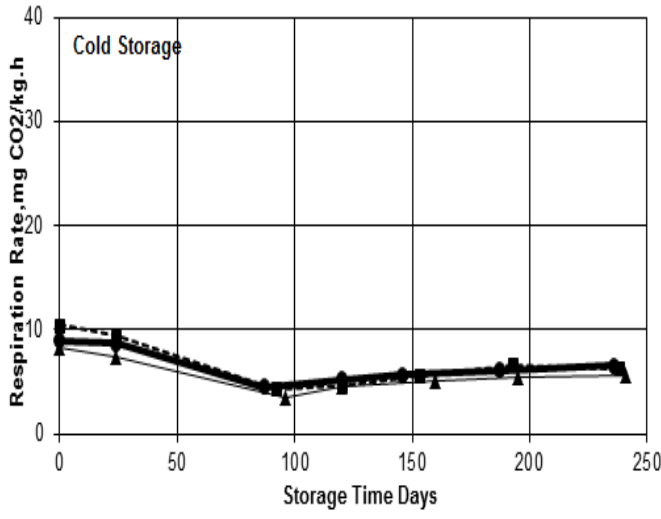

$\longrightarrow$ at $0.0 \mathrm{KPa}-\boldsymbol{m}-\boldsymbol{\text { at }} 2.44 \mathrm{KPa} \sim \boldsymbol{\sim}$ at $4.87 \mathrm{KPa}$

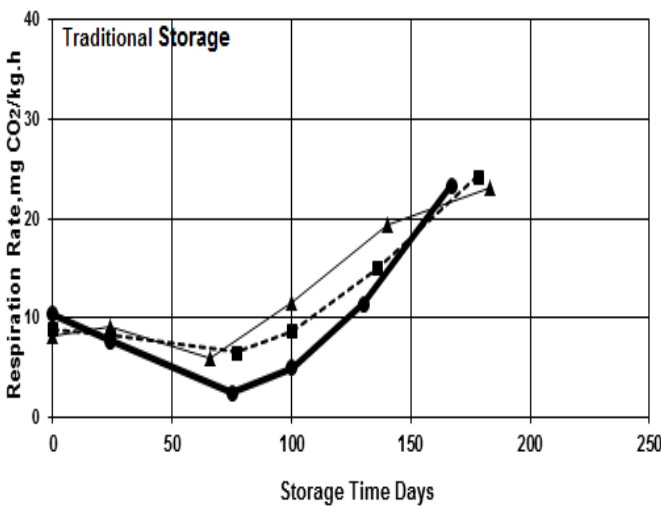

$\longrightarrow$ at $0.0 \mathrm{KPa}-\boldsymbol{- m}$ at $2.44 \mathrm{KPa} \sim$ at $4.87 \mathrm{KPa}$

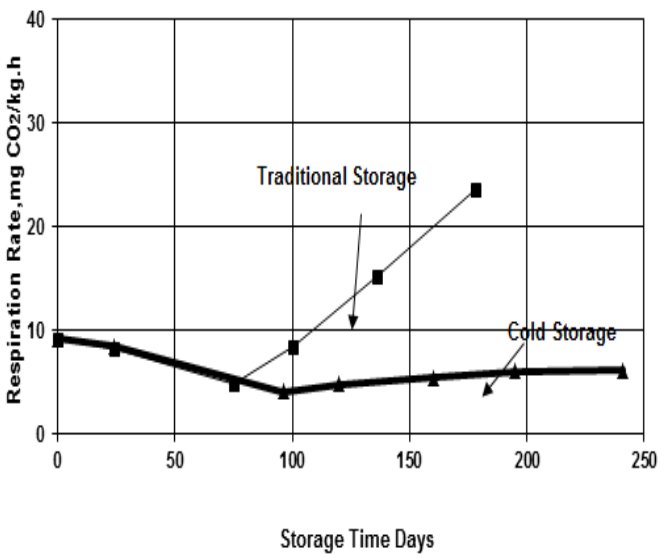

$\rightarrow$ At Cold Storage - - At Traditional Storage

Figure (8): Effect of Storage Time on Respiration Rate of Potato Tubers under Two Storage Conditions at Different Static Stress. 
Sand Soil

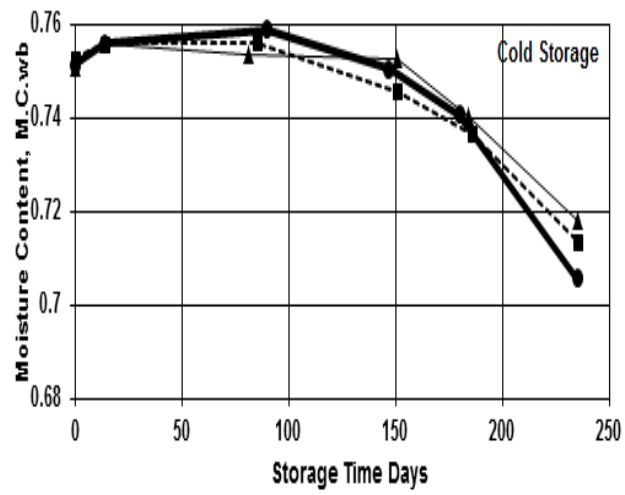

$\rightarrow$ At $0.0 \mathrm{KPa} \rightarrow--A t 2.44 \mathrm{Kpa} \rightarrow$ At $4.87 \mathrm{KPa}$

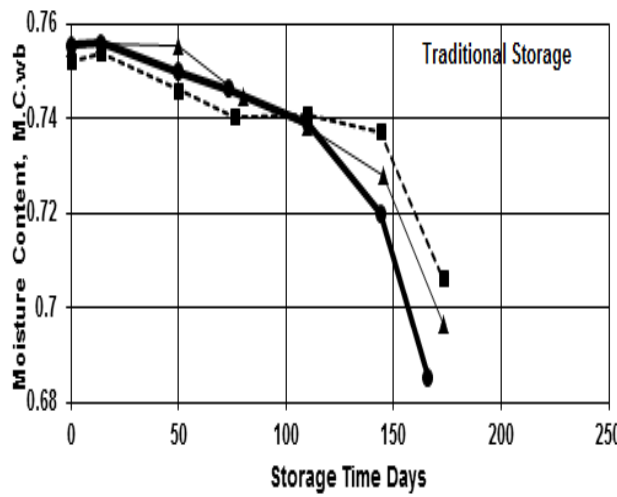

$\rightarrow$ At $0.0 \mathrm{KPa} \quad-\rightarrow-A t 2.44 \mathrm{Kpa} \rightarrow$ At $4.87 \mathrm{KPa}$

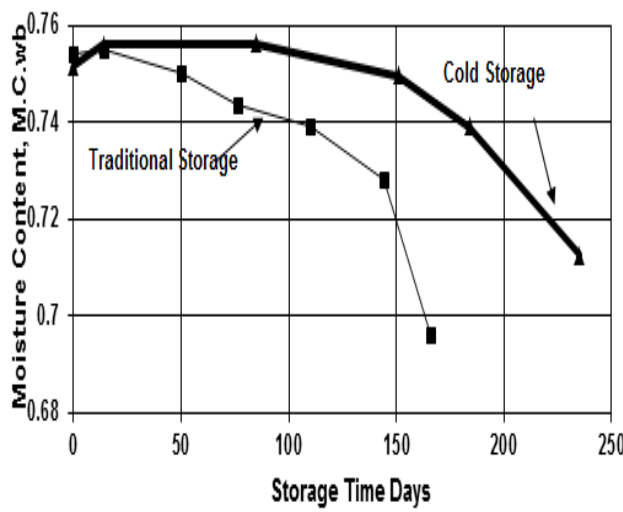

-at Cold Storage -at Traditional Storage
Black Soil

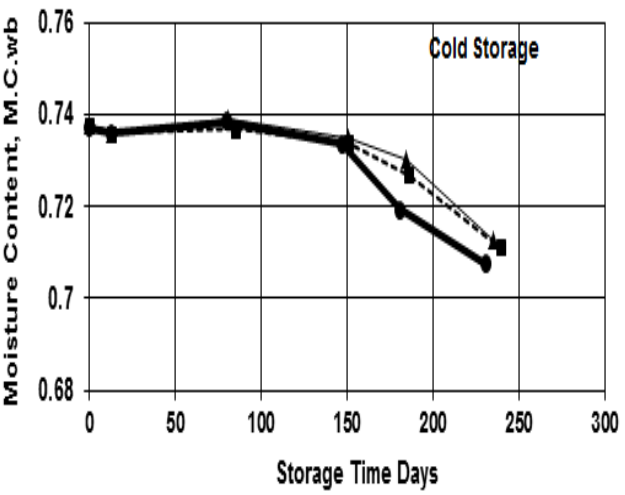

$\rightarrow$ At $0.0 \mathrm{KPa} \rightarrow-\mathrm{At} 2.44 \mathrm{Kpa} \rightarrow$ At $4.87 \mathrm{KPa}$

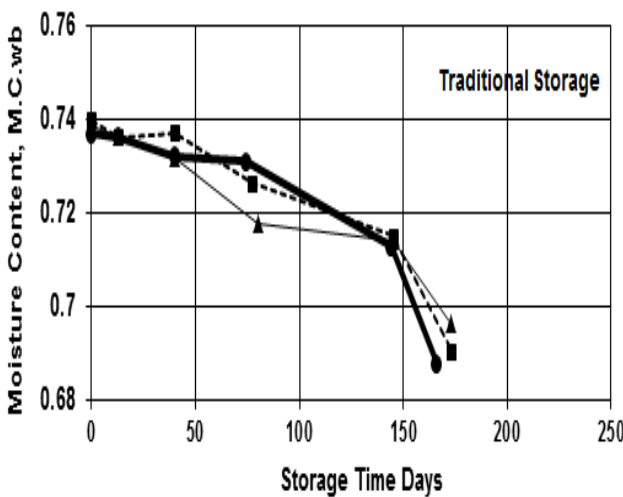

$\rightarrow$ At $0.0 \mathrm{KPa} \rightarrow-1 \mathrm{At} 2.44 \mathrm{Kpa} \rightarrow$ At $4.87 \mathrm{KPa}$

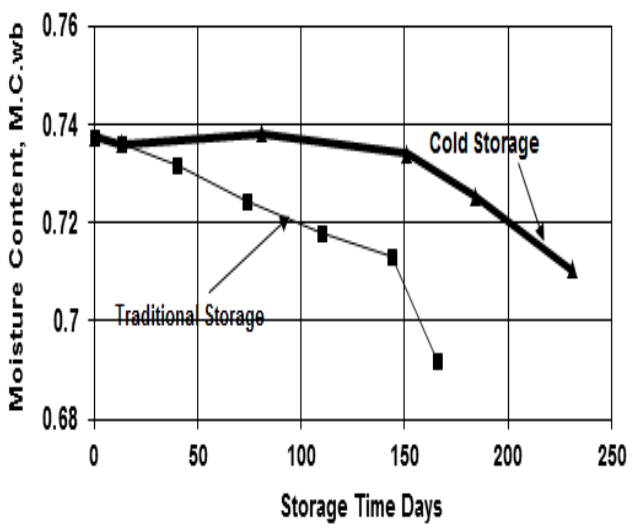

- at Cold Storage -at Traditional Storage

Figure (9): Effect of Storage Time on Moisture Content of Sand and Black Potato Tubers under Two Storage Conditions at Different Static Stress. 
The sugar content (S.C., Brix) of storage potato tubers were measured during storage time. Figures (10) represent the sugar content of storage potato tubers as a function of storage time for each of sand and black soil at different static load stress for different storage conditions(cold and traditional storage).

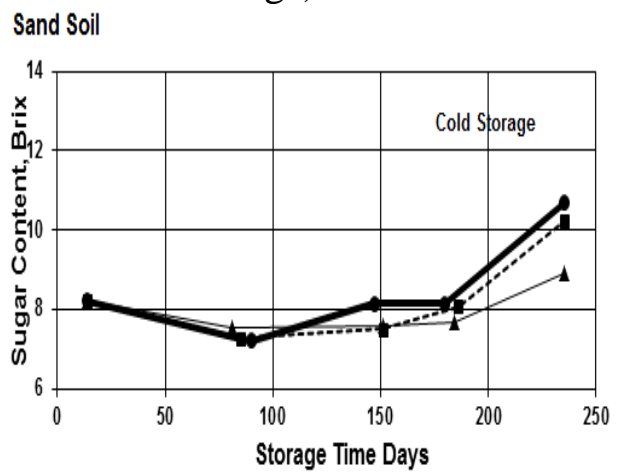

Black Soil
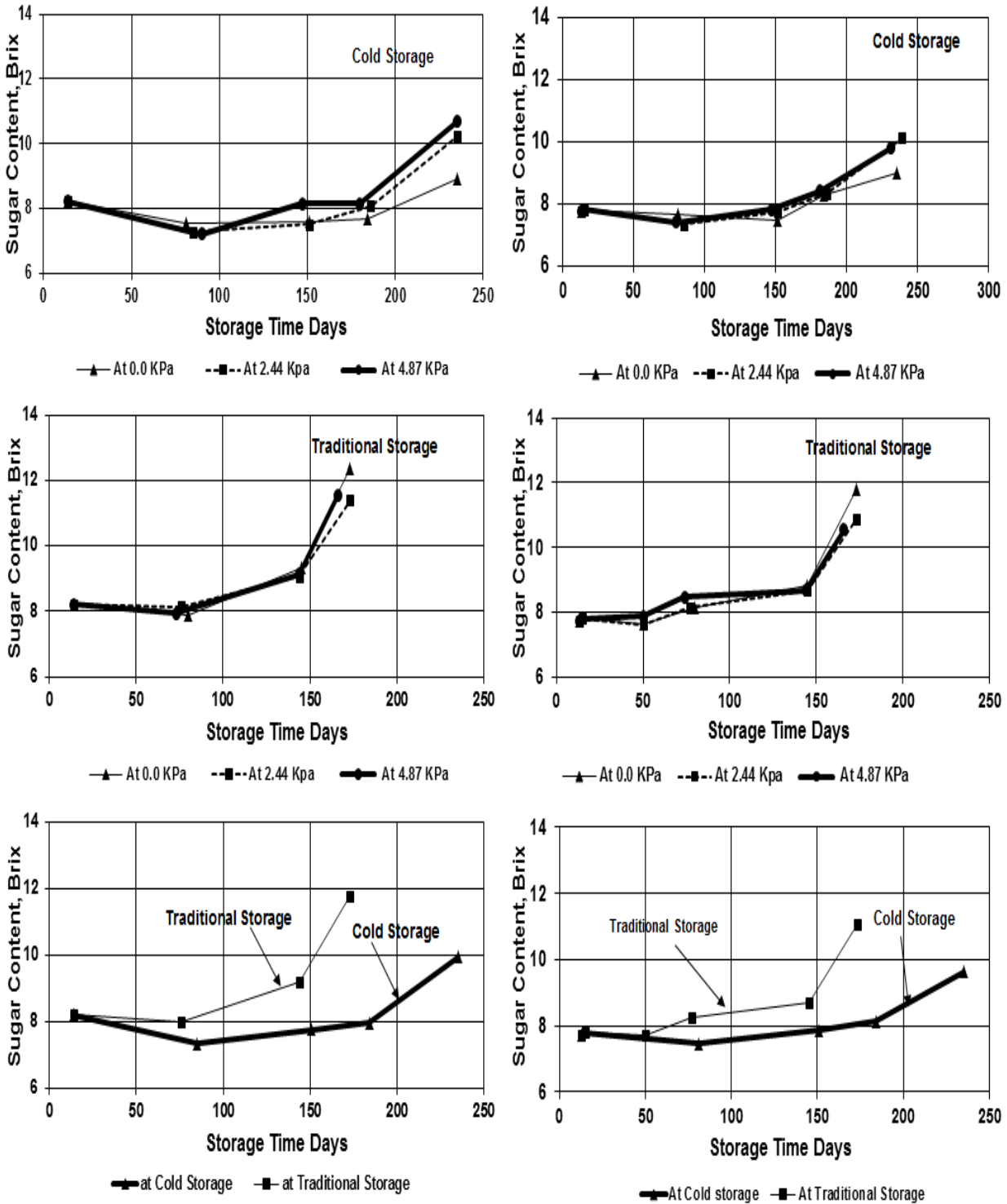

Figure (10): Effect of Storage Time on Sugar Content of Potato Tubers under Two Storage Conditions at Different Static Stress. 
The results show that sugar content (S.C., Brix) increases gradually with increasing storage time for each of sandy and black soil for all treatments under storage condition.

Linear multiple regression statistical analysis was conducted to clarify the relationship between sugar content (S.C., Brix) as a function of storage parameters. The statistical regression equations are as follow:

\section{For Sand Soil Cultivars:}

$$
\begin{array}{r}
\text { S.C., Brix }=0.1197 \mathrm{~T}+0.0809 \mathrm{SL}+0.0188 \mathrm{t}+0.0387 \mathrm{M} \\
\ldots \mathrm{R}^{2}=0.979, \mathrm{STD}=1.382 \ldots
\end{array}
$$

\section{For Black Soil Cultivars:}

$$
\begin{array}{r}
\text { S.C., Brix }=0.0795 \mathrm{~T}+0.0060 \mathrm{SL}+0.0191 \mathrm{t}+0.0432 \mathrm{M} \\
\ldots . \mathrm{R}^{2}=0.987, \mathrm{STD}=1.009 .
\end{array}
$$

The equations show that sugar content (S.C., Brix) positively affected by each of storage temperature, static load stress, storage time and tuber mass for each of sand and black soil cultivars.

\section{REFRENCES}

Bidwell, R.G.S. (1979). Plant Physiology. $2^{\text {nd }}$ Edition. Macmillan Publishing Co., Inc. New York.

Dewulf; W., P. Jancsok; B. Nicolai; G. De Roeckand D. Briassoulis (1999). Determining the Firmness of a Pear using Finite Element Modal Analysis.J. Agric .Engng Res (1999)74,217-224.

Eltawil, M., D. Samuel and O. Singhal (2006). Potato technology and store design aspects. Agricultural Engineering International: the CIGR Ejournal.InvitedOveriew No.11.Vol.VIII. April,2006.

Ghadge, A.D. ;M.G.Britton ; and D. S.Sayas (1989). Moisture content determination for potatoes. Transactions of the ASAE, 32(5): 17441746 .

Kader, A.A. (1987). Respiration and gas exchange of vegetables. Ch. 3. In Post Harvest, Physiology of Vegetables (Ed.) J. Weichmann, p. 25. Marcel Dekker Inc., New York.

Mohsenin, N.N. (1986). Physical Properties of Plant and Animal Materials. Gordon and Breach Science Publishes. New York, USA.

NPC, (J. of Nation. Potato Council), Jul 2016, Washington, D.C., USA). 
Sahin, Serpil and ServetGulumSumnu, (2006).Physical Properties of Food, Springer Sience and Business Media Publisher, LLC. (seed displacement technique)pp12-18.

Sastry, S.K. (1985). Factors affecting shrinkage of foods in refrigerated storage.ASAE Paper No, 85-15 No. 1.American Society of Agricultural Engineering, St. Joseph, MI 49085.

Singh, B.R, A.S. Agarwaland Y. Kanehiro (1969). Effect of chloride salts on Ammonium Nitrogen release in two Hawaiian soils. American Soil Science Society $33: 257-266$.

\section{الملخص العربيى}

الخصائص الطبيعية والفسيولوجية لارنات البطاطس والمرتبطة بظروف التخزين

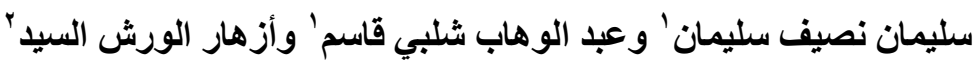

يهدف البحث إلى دراسة نأثير ظروف التخزين المختلفة علي جودة درنات البطاطس للصنف

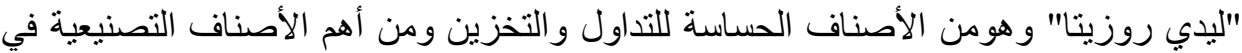

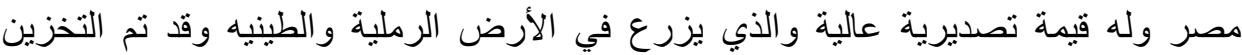

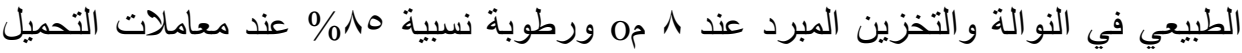

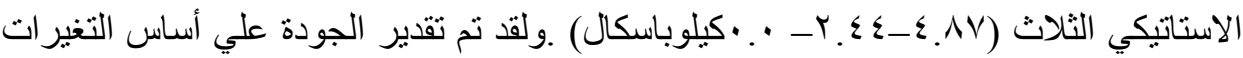

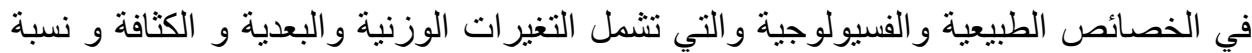

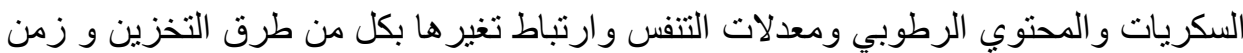

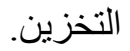

تم قياس الخصائص الطبيعية والفسيولوجية للدرنات المخزنة مرة كل شهر تقريبا ولقد اجري

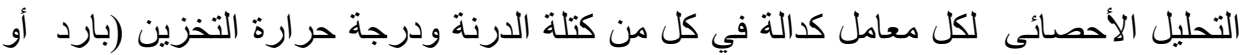

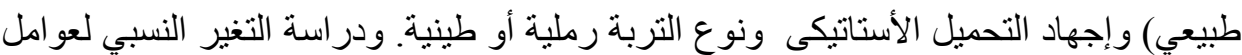

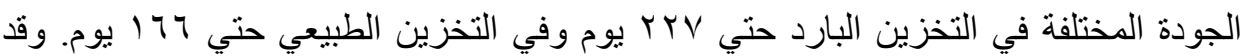

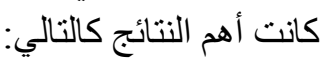

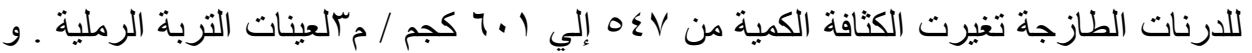

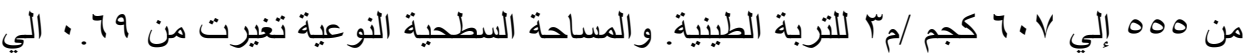

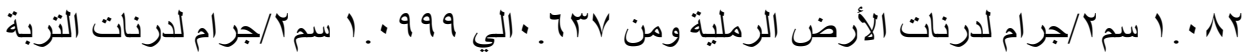

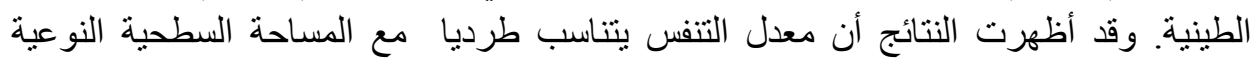

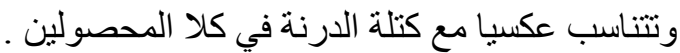




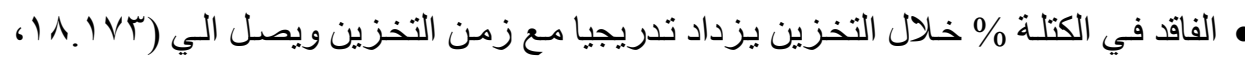

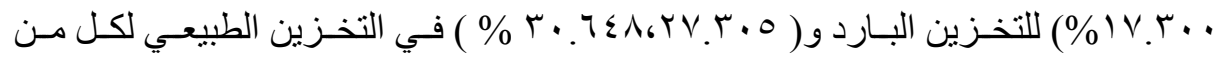
محصولي الأرض الرملية والطينية علي التوالي.

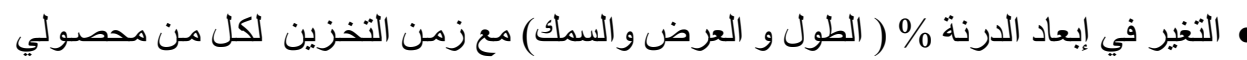

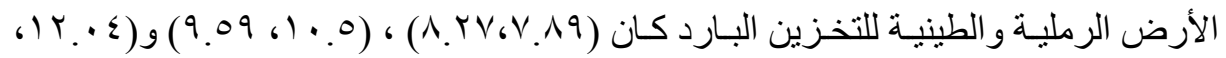

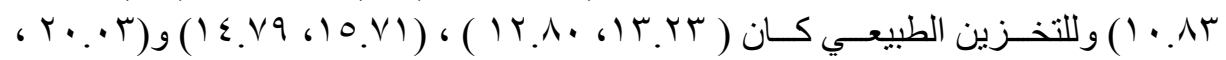

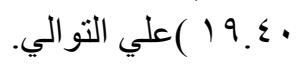
• معدل التنفس للارنات المخزنة يقل تدريجيا مع زيادة زمن التخزين (فترة سكون) حتى بداية

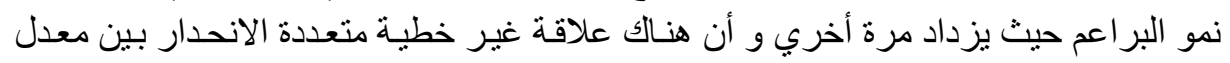

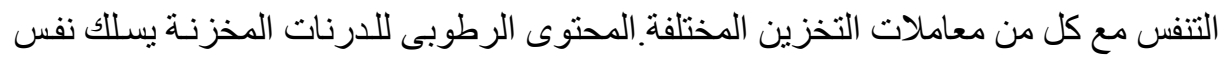

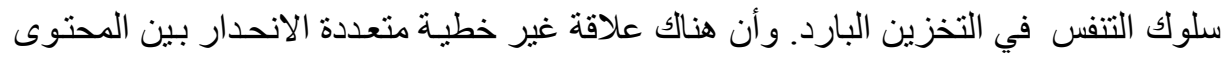

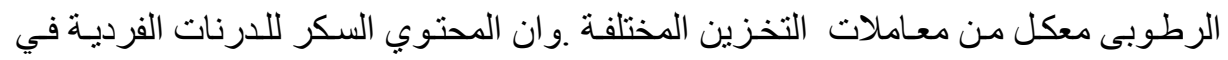

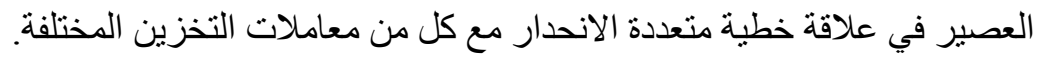

